\title{
Using Inter Simple Sequence Repeat Multi-Loci Markers for Studying Genetic Diversity in Guppy Fish
}

\author{
Mohammadreza Mohammadabadi ${ }^{1, *}$ (D), Valentyna Oleshko ${ }^{(D)}$, Olexandr Oleshko (D), \\ Leonid Heiko ${ }^{(\mathbb{D})}$, Iryna Starostenko ${ }^{(\mathbb{D})}$, Jurii Kunovskii ${ }^{(\mathbb{D})}$, Alevtina Bazaeva ${ }^{4}$, Zahra \\ Roudbari $^{5}$
}

\begin{abstract}
${ }^{1}$ Shahid Bahonar University of Kerman, Faculty of Agriculture, Department of Animal Science, Kerman, Iran.
${ }^{2}$ Bila Tserkva National Agrarian University, Department of Aquaculture, Bila Tserkva, Ukraine.

${ }^{3}$ Bila Tserkva National Agrarian University, Department of Animal Science, Bila Tserkva, Ukraine.

${ }^{4}$ National University of Life and Environmental Sciences of Ukraine, Department of Hydrobiology and Ichthyology.

${ }^{5}$ University of Jiroft, Faculty of Agriculture, Department of Animal Science, Jiroft, Iran.
\end{abstract}

\section{How to cite}

Mohammadabadi, M., Oleshko, V., Oleshko, O., Heiko, L., Starostenko, I., Kunovskii, J., Bazaeva, A., Roudbari, Z. (2021). Using Inter Simple Sequence Repeat Multi-Loci Markers for Studying Genetic Diversity in Guppy Fish. Turkish Journal of Fisheries and Aquatic Sciences, $21,603-613$. http://doi.org/10.4194/1303-2712-v21_12_03

\section{Article History}

Received 24 March 2021

Accepted 08 August 2021

First Online 11 August 2021

\section{Corresponding Author \\ Tel.: +989133987534 \\ E-mail:mrm@uk.ac.ir}

\section{Keywords}

Aquarium fish industry

Phylogenetic tree

Polymorphism

ISSR markers

\begin{abstract}
The aquarium fish industry has become a capacity for job creation and income generation. Aquarium fish were used for decoration and are creating tranquility in the environment and beautification in public places. This study investigated genetic variation between different populations of various varieties of guppy ornamental aquarium fish using inter simple sequence repeat (ISSR) markers in Iran for the first time. DNA was extracted from twelve strains. The polymerase chain reaction was performed using seven ISSR primers. GenAlex 6.501 and XLSTAT software were used to analyze data. Results of analysis of molecular variance showed that $54 \%$ of observed polymorphism belongs to variance among populations, and $46 \%$ corresponds to diversity between populations. The highest and the lowest polymorphism percentage belonged to (GAG)5GC (90\%) and (AG)8C (41\%) markers, respectively. The percentage of polymorphic loci ranges from $32.31 \%$ to $86.15 \%$. The results of the phylogenetic tree showed that this tree was divided into two major clusters. Cluster I included only two populations and cluster II contained the other ten studied populations. It is suggested that this marker system was efficient in discriminating each genotype at the molecular level and can be used for genetic diversity analysis for aquarium guppy fish because a greater understanding of the species' potential is necessary for supporting long-term genetic improvement.
\end{abstract}

\section{Introduction}

With the increasing use of aquarium fish for decoration and creating tranquility in the environment, and beautification in public places, the aquarium industry has become an essential source for job creation and income generation. Annually, about 200 million pieces of aquarium fish are bred and reproduced in Iran. Among the ornamental aquarium fish, guppies (Poecilia reticulata) are one of the most important and popular fish (Kucuk, 2009). Researchers have created various varieties in terms of body shape and color by performing different crosses between guppies (Khoo et al., 2003; Kucuk, 2009). The guppy is a live-bearing fish used as a model creature for population genetics studies (Suk and Neff, 2009), growth, aging, inbreeding depression, and heterosis (Shen et al., 2007). 
The agglomeration of inbreeding and the detriment of genetic diversity is anxiety in animal conservation (Barazandeh et al., 2012; Shamsalddini et al., 2016). Inbreeding enhances the danger of surrogating a rare recessive genetic disease and diminishes the population's fitness (Nassiry et al., 2005; Vajed Ebrahimi et al., 2017). In addition to that, plenary exploration of the breed specifications is necessary for impressive management of genetic resources in animals (Kharrati Koopaei et al., 2012; Moghadaszadeh et al., 2015). The utilization of molecular genetics has very significant benefits (Mohammadi et al., 2009; Gholamhoseini et al., 2018). One of the most important advantages is the genotyping of individuals for particular genetic loci (Mohammadabadi et al., 2010; Pasandideh et al., 2015).

Inter Simple Sequence Repeat (ISSR) is the genome region between microsatellite loci (Mohammadabadi 2017). The ISSR is a molecular marker method, which does not need the genome sequence information and leads to multi-loci and highly polymorphic patterns (Zamani et al., 2011). Each ISSR band corresponds to a DNA sequence delimited by two inverted microsatellites. The ISSR loci are dominant markers with the assumption of only two alleles per locus. It has been shown that the ISSR markers are universal, quick, easy to apply, highly reproducible, and polymorphous (Zamani et al., 2011). Their utility has been confirmed in various studies, such as detection of somaclonal variation (Leroy et al., 2000; Sarwat, 2012), genetic stability (Yuan et al., 2009; Lata et al., 2010; Zhang et al., 2010), gene tagging (Ammiraju et al., 2001; Marczewski et al., 2002), cultivar identification (Nagaraju et al., 2002), hybrid identification (Lin et al., 2010) and phylogenetic studies (Paris et al., 2003; Han et al., 2010), genetic relatedness, (Rajwade et al., 2010), and also to determine production quality (Tamhankar et al., 2009; Wu et al., 2010; Sarwat, 2012). Although ISSR markers have many advantages, it should be noted that these markers are dominant, so heterozygotes cannot be distinguished from homozygotes. Therefore, compared to codaminant markers, this is a defect for ISSR markers.

Carvalho et al. (1991) used allozymes to investigate genetic diversity between populations of the guppy fish. In another study, Fajen and Breden (1992) investigated genetic diversity for different populations of guppy fish using mitochondrial DNA. Many researchers (Becher et al., 2002; Watanabe et al., 2003; Paterson et al., 2005) have used microsatellite markers for studying genetic variations in the guppy fish. In the earliest, Suk and Neff (2009) used microsatellite markers to study genetic diversity in 15 populations, including 373 fishes of Trinidadian guppies (Poecilia reticulata). They showed a high level of genetic diversity between studied populations. RADP markers have also been used for determining genetic diversity between guppy fishes (Kucuk, 2009).

In comparison with mentioned used markers, ISSR markers are helpful to investigate population genetic studies, gene mapping, germplasm identification, and characterize gene bank accessions and identify closely related populations. ISSRs are also simpler, faster, cheaper (Sarwat, 2012), unnecessary to know the genetic background of the fish studied to investigate genetic diversity based on ISSR markers (Zamani et al., 2011). However, no attempt has been made to characterize the genetic diversity of guppy ornamental aquarium fish through ISSRs. Hence, this study aimed to investigate genetic variation between different populations of various guppy ornamental aquarium fish using ISSR markers in Iran for the first time.

\section{Materials and Methods}

\section{Fish Varieties}

Twelve strains of aquarium guppy fish (Green Red Dragon, German Platinum Crown Tail, Blue Moscow, Blue Moscow Albino, Black Moscow, Mozaic, Red Mozaic, Super Red Singapore, Japan Blue, Full of Black Thai, Metal Lace Thailand, and Cobra) were bought from various aquarium fish shops. 30 fish were selected from each strain. A total of 360 fish were used in our study.

\section{Sampling and DNA Extraction}

Due to the small size of the fish, part of the muscle tissue in the fish's abdomen was removed for DNA extraction. The removed part of muscle tissue was added to $500 \mathrm{ml}$ of TES buffer including proteinase $\mathrm{K}(200 \mathrm{mg} / \mathrm{ml}), 150 \mathrm{mM} \mathrm{NaCl}, 50 \mathrm{mM}$ Tris-HCl (pH 8.0), and $25 \mathrm{mM}$ EDTA (pH 8.0) via the Phenol: Chloroform: Isoamyl Alcohol procedure (Sambrook and Russell 2001) to extract total DNA. Both spectrophotometry and agarose gel $(1 \%)$ were applied to determine the quality of extracted DNA. 


\section{Selection of Primers}

From the various ISSR primers used to study the genetic diversity of fish, (AG)8G, (GAG)5GC, (CA)8AG, (GTG)5GC, (AG)8C, (GACA)4, and (CA)8AC primers (Table 1) which had higher polymorphisms and were better amplified than other primers were selected (Labastida et al., 2015).

\section{Polymerase Chain Reaction}

Amplification of DNA was carried out in a 25 $\mu \mathrm{L}$ PCR reaction. Each reaction consisted of 20 $\mathrm{ng} / \mu \mathrm{l}$ DNA, $2.5 \mu \mathrm{L}$ PCR buffer, $200 \mu \mathrm{M}$ of each dNTP, $3 \mathrm{mM} \mathrm{MgCl2}, 0.3 \mu \mathrm{L}$ Taq DNA polymerase, sterile water was added until the reaction volume reached $25 \mu \mathrm{L}$. The PCR condition was $94^{\circ} \mathrm{C}$ for 5 $\min$ (initial denaturation); $94^{\circ} \mathrm{C}$ for $45 \mathrm{~s}$ (denaturation), annealing temperature which differed for each primer and ranged from 56 to 66 ${ }^{\circ} \mathrm{C}$ (Table 1 ) and $72^{\circ} \mathrm{C}$ for 2 min (extension) for 40 cycles; $72^{\circ} \mathrm{C}$ for $7 \mathrm{~min}$ (final extension). Negative controls were also used. The PCR products were electrophoresed on $1 \%$ agarose gel with $1 \times \mathrm{TAE}$ buffer at $80 \mathrm{~V}$ for $2 \mathrm{~h}$ along with $0.1 \mathrm{~kb}$ ladder (CinnaGen Co., Iran). The gels were stained with ethidium bromide and visualized under UV light
(BTS-20.M, UVItec Ltd., UK). ONE-Dscan software (Scanalytics, Inc., Fairfax, VA) was applied to define the amplified fragments' size. Based on the presence or absence of the bands, the ISSR profiles were scored as 1 or 0 , respectively. It is assumed that in any locus, every created ISSR band is a dominant allele.

\section{Data Analysis}

A non-parametric analysis of molecular variance (AMOVA) (Excoffier et al., 1992) and Nei's genetic distance analysis were carried out using GenAlex 6.501 (Peakall \& Smouse, 2006) to characterize the genetic structure and variability between populations. XLSTAT (2017) was used to draw a phylogenetic tree for studied populations based on 7 ISSR markers. The principal component analysis (PCA) was performed using GenAlex 6.501 (Peakall \& Smouse, 2006).

Population structure was determined using STRUCTURE software version 2.3.4 and performed with a burn-in of 10000 iterations followed by 100 000 Markov chain Monte Carlo (MCMC) iterations under the admixture model. The analysis was run for the range of genetic clusters $(\mathrm{K})$ from $\mathrm{K}=2$ to $\mathrm{K}=$ 10 with five repetitions for each $K$. The optimum $K$

Table 1. Characteristics of used ISSR primers for studied guppy fish strains

\begin{tabular}{lcc}
\hline Primer & \multicolumn{1}{c}{ Primer sequence $\left(5^{\prime}-3^{\prime}\right)$} & Annealing Temperature $\left({ }^{\circ} \mathrm{C}\right)$ \\
\hline (AG)8G & 5'-AGA GAG AGA GAG AGA GG-3' & 56 \\
(GAG)5GC & 5'-GAG GAG GAG GAG GAG GC-3' & 63 \\
(CA)8AG & 5'-CAC ACA CAC ACA CAC AAG-3' & 60 \\
(GTG)5GC & 5'-GTG GTG GTG GTG GTG GC-3' & 66 \\
$($ AG)8C 8 5'-AGA GAG AGA GAG AGA GC-3' & 57 \\
$($ GACA)4 & 5'-GAC AGA CAG ACA GAC A -3' & 56 \\
(CA)8AC & 5'-CAC ACA CAC ACA CAC AAC-3' & 60 \\
\hline
\end{tabular}

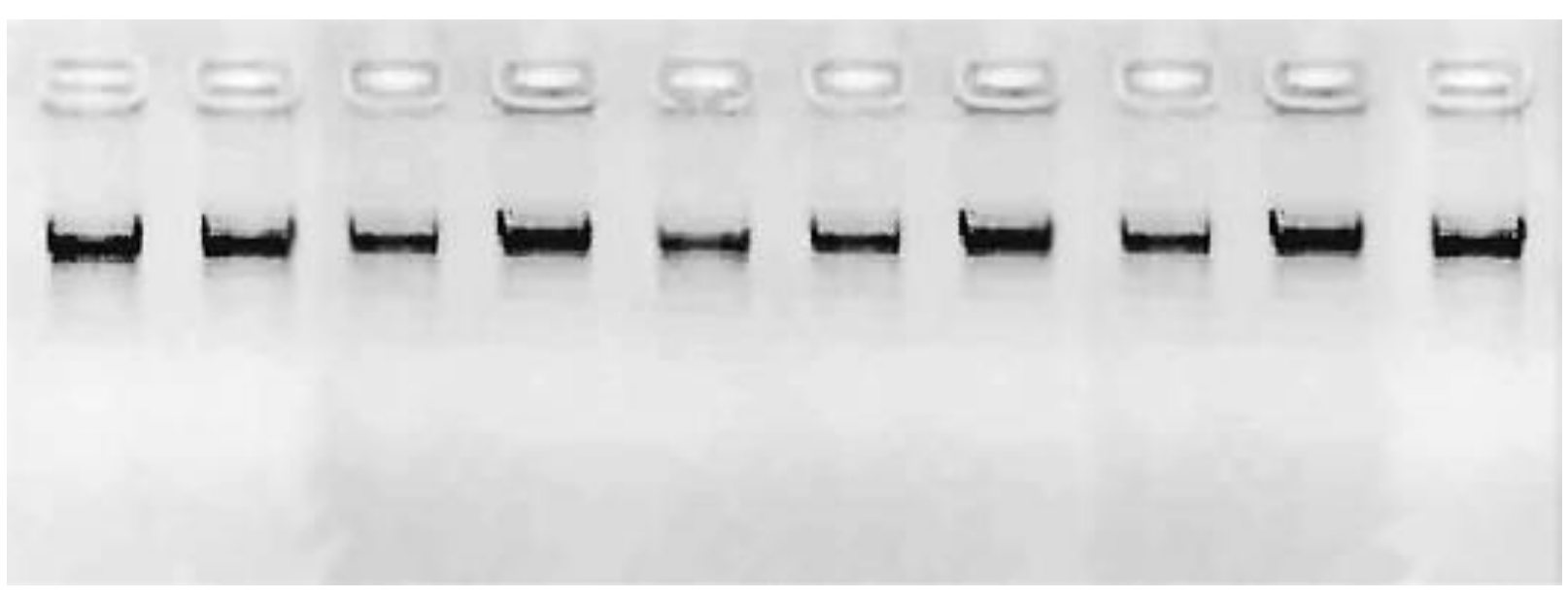

Figure 1. Quality of extracted DNA from studied guppy fish on $1 \%$ agarose gel 
was determined based on $\Delta \mathrm{K}$ calculated by the following equation:

$$
\Delta K=m\left|L^{\prime \prime}(K)\right| / s[L(K)]
$$

which is based on the rate of change in the log probability of data between successive $K$ values via the $\Delta K$ method of Evanno et al. (2005), using STRUCTURE HARVESTER (Earl and VonHoldt, 2012).

\section{Results}

The quality of the extracted DNA was suitable for further research (Figure 1). Using seven specific primers, PCR products were amplified as well (Figure 2). In all studied samples, the size of amplified PCR fragments varied from $100 \mathrm{bp}$ to 1800 bp (Table 2). The AMOVA analysis detected that $54 \%$ of observed polymorphism belongs to

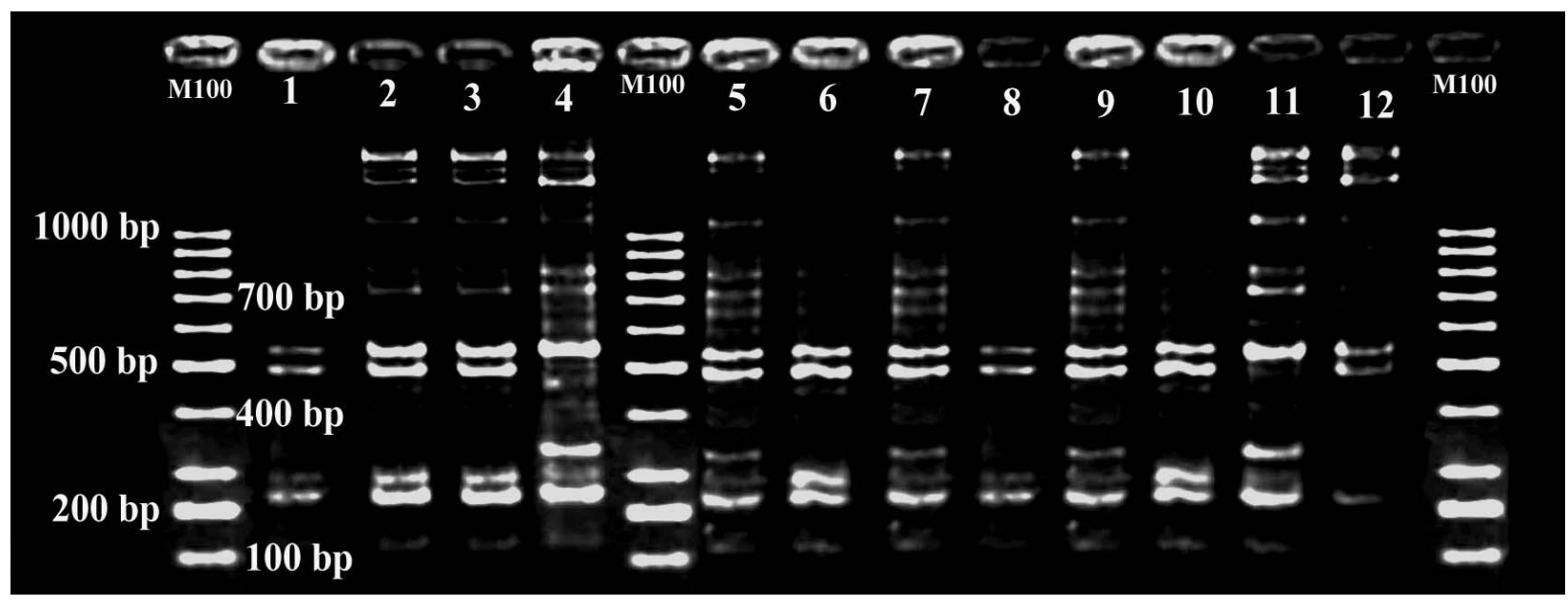

Figure 2. Profiles of two ISSR markers; (AG)8G and (GAG)5GC for twelve studied guppy fish on $2 \%$ agarose gel. Lines 2, 3, 4, 5, 7, 9, 11 and 12 correspond to (AG)8G marker and $1,6,8$ and 10 correspond to (GAG)5GC marker. M100 is DNA ladder

Table 2. Genetic diversity parameters over loci for each population using seven ISSR markers

\begin{tabular}{|c|c|c|c|c|c|c|c|c|}
\hline Population & & $\mathrm{N}$ & $\mathrm{Na}$ & $\mathrm{Ne}$ & 1 & $\mathrm{He}$ & $\mathrm{uHe}$ & $\mathrm{P} \%$ \\
\hline \multirow{2}{*}{ Green Red Dragon } & Mean & 30.000 & 1.662 & 1.291 & 0.300 & 0.186 & 0.189 & \multirow{2}{*}{$83.08 \%$} \\
\hline & SE & 0.000 & 0.094 & 0.039 & 0.029 & 0.021 & 0.021 & \\
\hline \multirow{2}{*}{ German Platinum Crown Tail } & Mean & 30.000 & 1.477 & 1.191 & 0.197 & 0.119 & 0.121 & \multirow{2}{*}{$73.85 \%$} \\
\hline & SE & 0.000 & 0.110 & 0.038 & 0.028 & 0.020 & 0.021 & \\
\hline \multirow{2}{*}{ Blue Moscow } & Mean & 30.000 & 0.892 & 1.315 & 0.258 & 0.177 & 0.180 & \multirow{2}{*}{$44.62 \%$} \\
\hline & SE & 0.000 & 0.124 & 0.050 & 0.038 & 0.026 & 0.027 & \\
\hline \multirow{2}{*}{ Blue Moscow Albino } & Mean & 30.000 & 0.646 & 1.255 & 0.199 & 0.139 & 0.141 & \multirow[b]{2}{*}{$32.31 \%$} \\
\hline & SE & 0.000 & 0.117 & 0.049 & 0.037 & 0.026 & 0.026 & \\
\hline \multirow{2}{*}{ Black Moscow } & Mean & 30.000 & 0.954 & 1.225 & 0.209 & 0.135 & 0.137 & \multirow{2}{*}{$47.69 \%$} \\
\hline & SE & 0.000 & 0.125 & 0.042 & 0.032 & 0.023 & 0.023 & \\
\hline \multirow{2}{*}{ Mozaic } & Mean & 30.000 & 1.677 & 1.575 & 0.461 & 0.315 & 0.320 & \multirow{2}{*}{$83.08 \%$} \\
\hline & SE & 0.000 & 0.091 & 0.051 & 0.033 & 0.024 & 0.025 & \\
\hline \multirow{2}{*}{ Red Mozaic } & Mean & 30.000 & 1.692 & 1.346 & 0.344 & 0.218 & 0.222 & \multirow{2}{*}{$84.62 \%$} \\
\hline & SE & 0.000 & 0.090 & 0.040 & 0.029 & 0.021 & 0.021 & \\
\hline \multirow{2}{*}{ Super Red Singapore } & Mean & 30.000 & 1.692 & 1.189 & 0.225 & 0.129 & 0.131 & \multirow{2}{*}{$84.62 \%$} \\
\hline & SE & 0.000 & 0.090 & 0.033 & 0.024 & 0.017 & 0.018 & \\
\hline \multirow{2}{*}{ Japan Blue } & Mean & 30.000 & 1.077 & 1.308 & 0.269 & 0.179 & 0.182 & \multirow{2}{*}{$53.85 \%$} \\
\hline & SE & 0.000 & 0.125 & 0.047 & 0.035 & 0.025 & 0.025 & \\
\hline \multirow{2}{*}{ Full of Black Thai } & Mean & 30.000 & 1.569 & 1.349 & 0.323 & 0.208 & 0.211 & \multirow{2}{*}{$78.46 \%$} \\
\hline & SE & 0.000 & 0.103 & 0.046 & 0.032 & 0.023 & 0.024 & \\
\hline \multirow{2}{*}{ Metal Lace Thailand } & Mean & 30.000 & 1.231 & 1.260 & 0.250 & 0.159 & 0.162 & \multirow{2}{*}{$61.54 \%$} \\
\hline & SE & 0.000 & 0.122 & 0.041 & 0.032 & 0.023 & 0.023 & \\
\hline \multirow{2}{*}{ Cobra } & Mean & 30.000 & 1.754 & 1.563 & 0.456 & 0.309 & 0.315 & \multirow{2}{*}{$86.15 \%$} \\
\hline & SE & 0.000 & 0.079 & 0.051 & 0.032 & 0.024 & 0.025 & \\
\hline \multirow{2}{*}{ All populations } & Mean & 30.000 & 1.360 & 1.322 & 0.291 & 0.189 & 0.193 & $67.82 \%$ \\
\hline & SE & 0.000 & 0.033 & 0.013 & 0.010 & 0.007 & 0.007 & $5.47 \%$ \\
\hline
\end{tabular}

${ }^{*} \mathrm{Na}=$ No. of Different Alleles, $\mathrm{Ne}=$ No. of Effective Alleles, I $=$ Shannon's Information Index, He $=$ Expected Heterozygosity, uHe $=$ Unbiased Expected Heterozygosity, P\%= Percentage of Polymorphic Loci 
Table 3. The AMOVA (Analysis of Molecular Variance) calculated by the GeneAlex 6.41 (Peakall and Smouse, 2006) for twelve strains of aquarium guppy fish using seven ISSR markers

\begin{tabular}{|c|c|c|c|c|c|}
\hline Source & $\mathrm{df}$ & SS & MS & Est. Var. & $\%$ \\
\hline Among populations & 11 & 2470.122 & 224.557 & 7.280 & $54 \%$ \\
\hline Within populations & 348 & 2141.267 & 6.153 & 6.153 & $46 \%$ \\
\hline Total & 359 & 4611.389 & & 13.433 & $100 \%$ \\
\hline
\end{tabular}

\section{Rescaled Distance Cluster Combine}

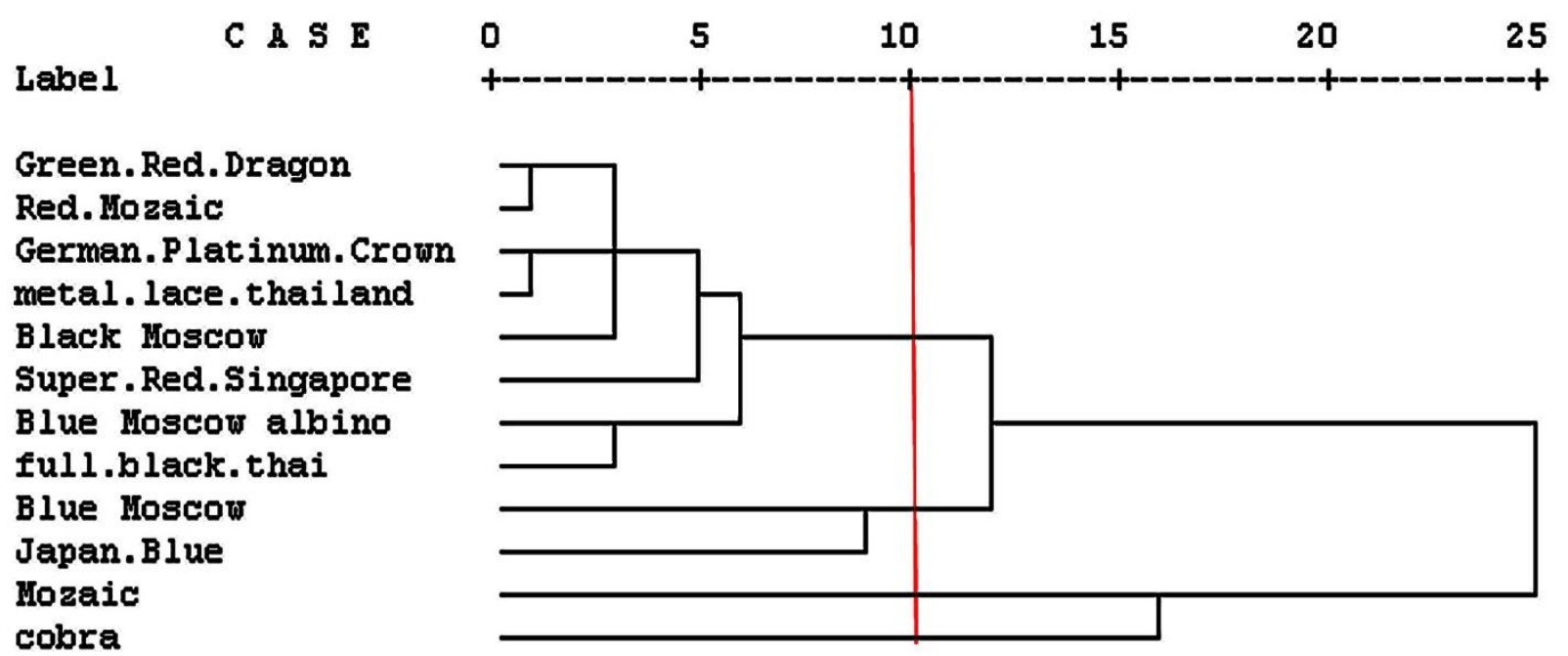

Figure 3. Dendrogram represent similarity coefficients of twelve strains of aquarium guppy fish in assessing the phylogenetic relationships using ISSR markers

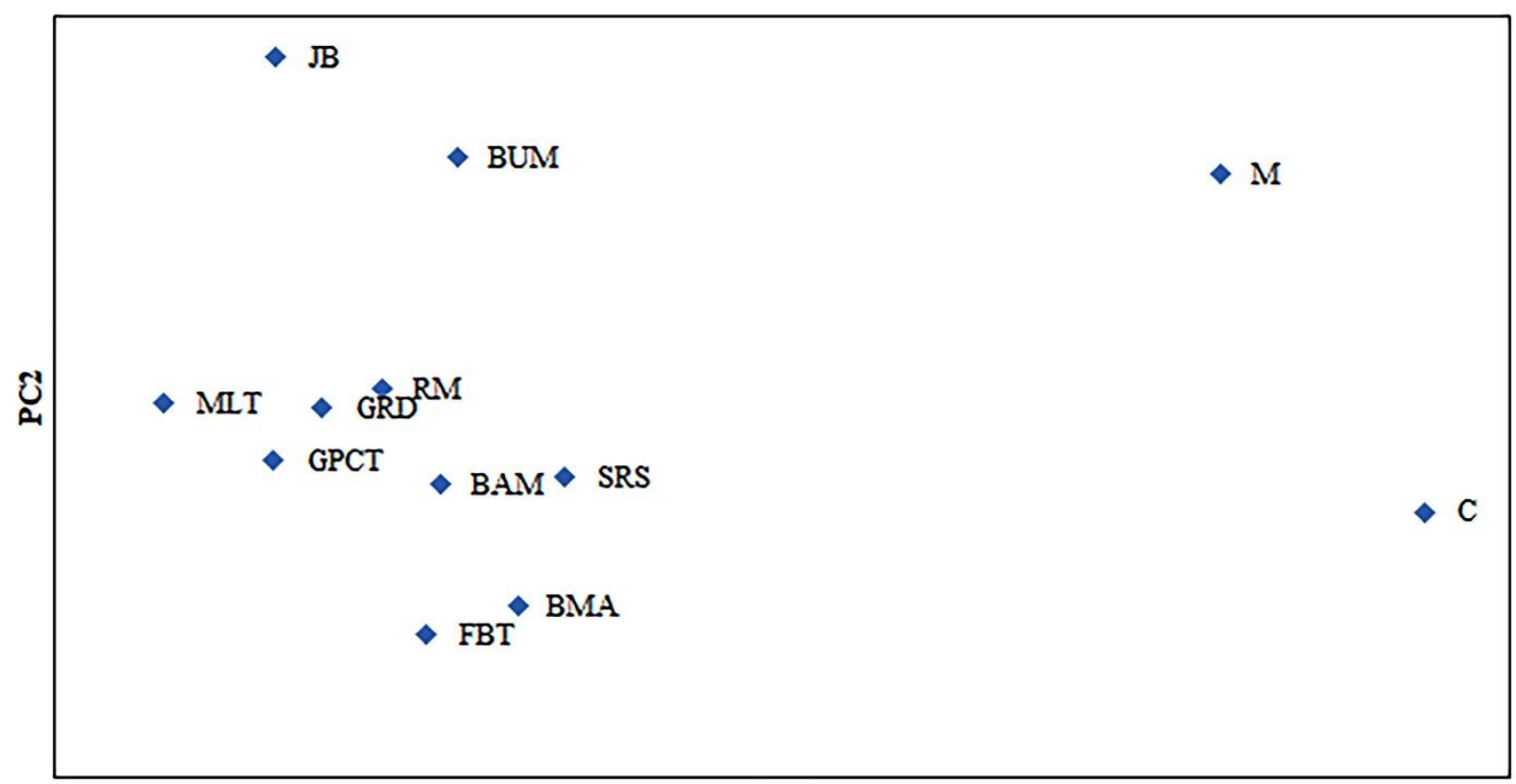

PCl

Figure 4. The populations clustering base on principal components analysis for twelve strains of aquarium guppy fish using seven ISSR markers. The proportion of total variation explained by first and second principal components, were 29.60 and $23.58 \%$, respectively. GRD=Green Red Dragon, GPCT=German Platinum Crown Tail, BUM=Blue Moscow, BMA= Blue Moscow Albino, $\mathrm{BAM}=$ Black Moscow, $\mathrm{M}=$ Mozaic, $\mathrm{RM}=$ Red Mozaic, $\mathrm{SRS}=$ Super Red Singapore, JB=Japan Blue, $\mathrm{FBT}=$ Full of Black Thai, MLT=Metal Lace Thailand and $\mathrm{C}=$ Cobra 
variance among populations, and $46 \%$ corresponds to diversity within populations (Table 3). The highest and the lowest polymorphism percentage belonged to (GAG)5GC (90\%) and (AG)8C (41\%) markers, respectively. Our results showed that the highest percentage of polymorphic loci belongs to Cobra population (86.15\%), and the lowest corresponds to Blue Moscow Albino population (32.31\%). Other polymorphic indices, such as Shannon's information index (I), for these two populations also confirm estimated diversity (Table 2). Finally, we observed 489 bands for used ISSR markers on studied populations, Green Red Dragon: 48 bands, German Platinum Crown Tail: 29 bands, Blue Moscow: 29 bands, Blue Moscow Albino: 21 bands, Black Moscow: 31 bands, Mozaic: 56 bands, Red Mozaic: 49 bands, Super Red Singapore: 47 bands, Japan Blue: 35 bands, Full of Black Thai: 47 bands, Metal Lace Thailand: 39, and Cobra: 58 bands.

The dendrogram was drawn using coefficients of twelve strains of aquarium guppy fish in assessing the phylogenetic relationships using ISSR markers (Figure 3 ). The phylogenetic tree results showed that this tree was divided into two major clusters (Figure 3). Cluster I included only two populations Mozaic and Cobra, and cluster II contained the other ten studied populations. Cluster II is divided into two sub-clusters. The first sub-cluster included two populations; Blue Moscow and Japan Blue, and the second subcluster contained eight populations; Green Red Dragon, German Platinum Crown Tail, Blue Moscow Albino, Red Mozaic, Super Red Singapore, Full of Black Thai, Metal Lace Thailand, and Black Moscow.

The populations clustering base on principal components analysis for twelve strains of aquarium guppy fish using seven ISSR markers is shown in Figure 4. The proportion of total variation explained by the first and second principal components were 29.60 and $23.58 \%$, respectively. As this figure shows, two populations Mozaic and Cobra, are located far from the other ten populations. Between these ten populations, two populations Blue Moscow and Japan Blue, are separated from the other eight populations. These results were in agreement with the phylogenetic tree (Figure 3).

The number of clusters $(K)$ present in twelve strains of aquarium guppy fish was determined by structure analysis based on the method adopted by Evanno et al. (2005). According to the results obtained by HARVESTER STRUCTURE, the highest level of $\Delta K$ corresponded to $K=3$ (Figure 5 and Figure 6). Based on the population structure analysis, strains were separated into three groups (Red, green and blue) with different genetic structures (Figure 6). As seen in this figure, two populations, Mozaic and Cobra (populations 6 and 12) with blue color, have high genetic similarity, and the other two populations Blue Moscow and Japan Blue (populations 3 and 9) with green color, have high genetic similarity with each other. These results were in agreement with the phylogenetic tree and PCA analysis.

\section{Discussion}

We studied the genetic diversity between different populations of 12 various guppy ornamental aquarium fish species using ISSR markers, which are useful for investigating genetic polymorphism in different fishes (Tong et al., 2005; Saad et al., 2012). The observed bands in this study are considered sufficient for species determination and studies of population genetics. Moreover, other molecular investigations for studying population genetics in fish species reported a similar number of bands and have confirmed our results. Labastida et al. (2015) studied lionfish in Cuba using ISSR markers and observed 113 bands ((GACA)4WB: 18 bands; (CA)8AC: 17 bands; (CA)8AG: 23 bands; (AG)8YC: 24 bands and (GAG)5GC: 31 bands) on 34 individuals. Casu et al. (2009) studied Dentex dentex L. 1758 (Perciformes, Sparidae) using 8 ISSR primers and reported 97 fragments. Liu et al. (2008) investigated Cynoglossus semilaevis Günther, 1873 (Pleuronectiformes, Cynoglossidae) applying 19 ISSR markers and identified 137 bands. A study on cyprinodontiform fish using 9 ISSR primers showed 101 bands (Maltagliati et al. 2006). Foo et al. (1995) studied the inheritance of RAPD markers in the Guppy fish, Poecilia reticulate. They used three oligonucleotide primers and their paired combinations (14 RAPD markers) for two guppy varieties, Green Snakeskin and Black, and showed that of these markers, $60 \%$ of them were polymorphic. In another investigation, Khoo et al. (2002) studied genetic diversity within and among feral populations and cultured strains of the guppy (Poecilia reticulate) by RAPD fingerprinting. They collected Feral guppies from 6 isolated populations (Bukit Timah, Nee Soon, Tuas, Mount Faber, Kranji, Laboratory-inbred feral lins) and sampled Tuxedo 


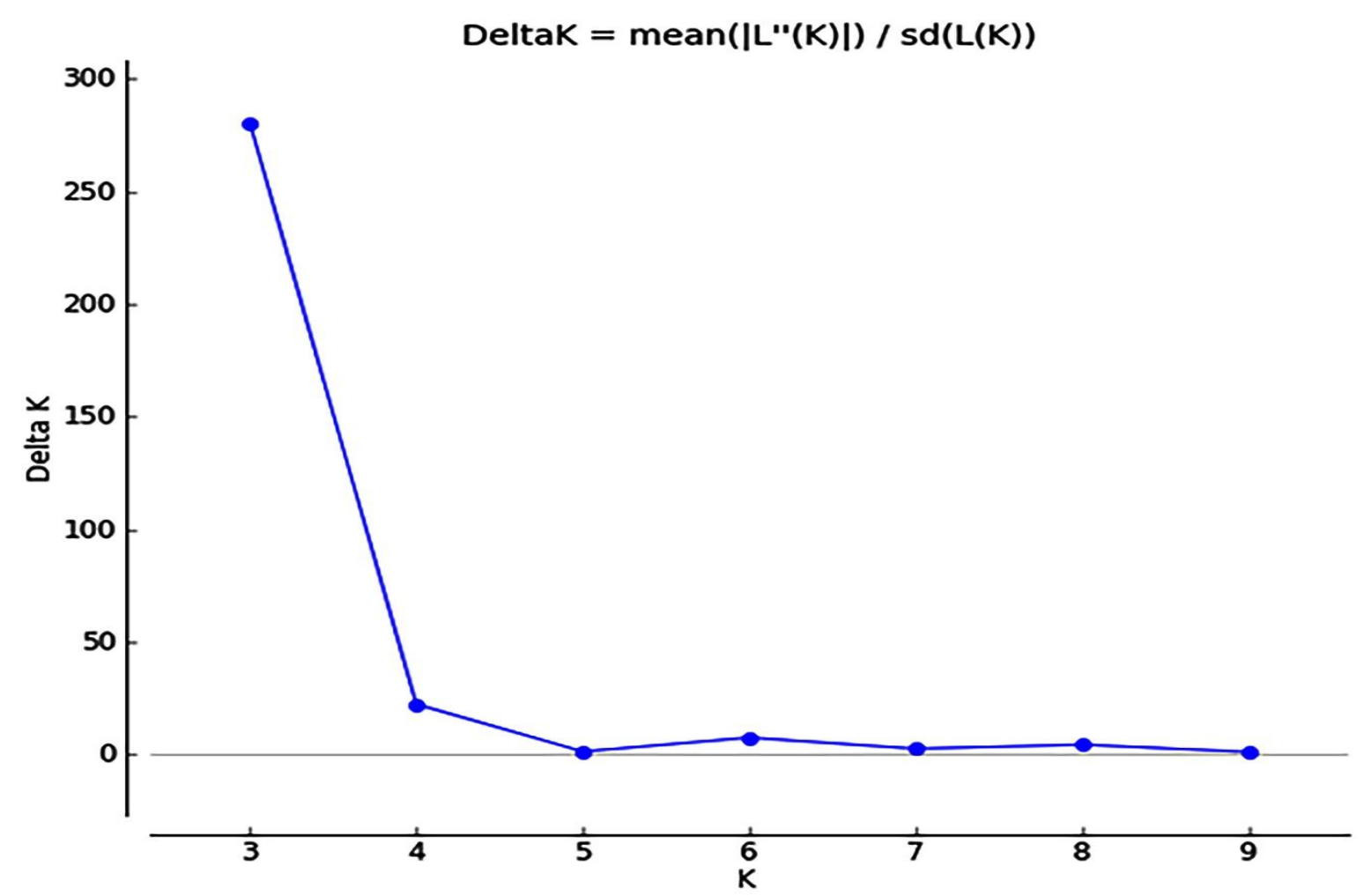

Figure 5. The graph (Delta K, K) of Evanno's method to determine the best K values for twelve strains of aquarium guppy fish using seven ISSR markers

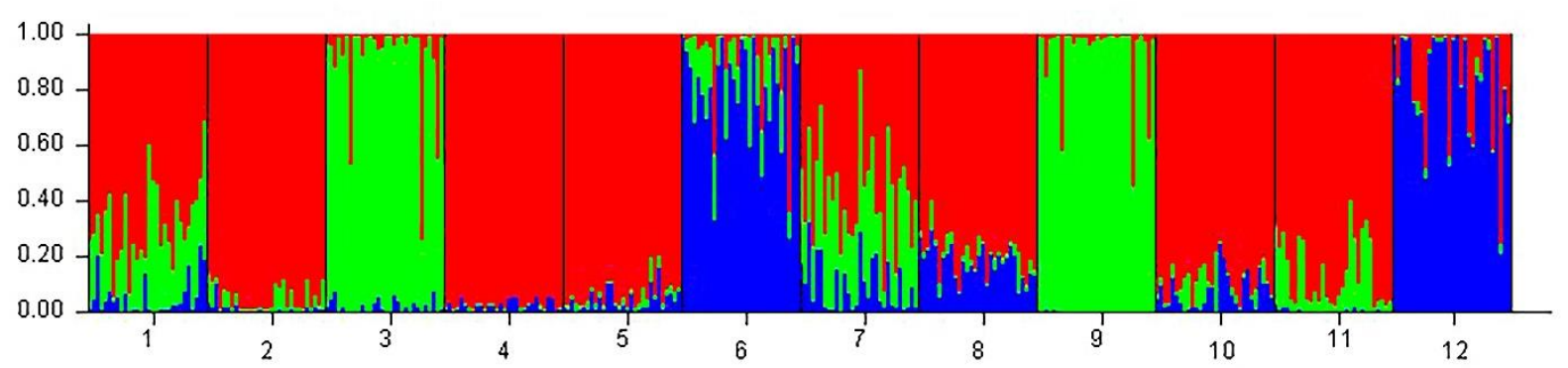

Figure 6. Biplot based on data obtained from seven ISSR primer combinations using the structure software for twelve strains of aquarium guppy fish. Red, green and blue indicate aquarium guppy fish divided into three subpopulations. 1=Green Red Dragon, 2=German Platinum Crown Tail, 3= Blue Moscow, 4=Blue Moscow Albino, 5=Black Moscow, 6=Mozaic, 7=Red Mozaic, 8=Super Red Singapore, 9=Japan Blue, 10=Full of Black Thai, 11=Metal Lace Thailand and 12=Cobra

and Green Variegated strains from 2 guppy farms in Singapore. They reported that the percentage of polymorphic loci ranged from $54.96 \%$ to $68.70 \%$. In contrast, the results of our current study showed that the percentage of polymorphic loci ranges from $32.31 \%$ to $86.15 \%$. This comparison demonstrates that genetic variations and polymorphism in studied Iranian guppies are higher than the guppy (Poecilia reticulate) in Singapore.

Shen et al. (2007) studied guppy (Poecilia reticulata) using fifty-one microsatellite DNA markers. They demonstrated that all of the markers show moderate allelic variation. The number of alleles for each locus ranged from two to 10. Observed and expected heterozygosities varied from 0.10 to 0.63 and from 0.23 to 0.77 , respectively. Suk and Neff (2009) studied genetic diversity in 15 populations, including 373 fishes of Trinidadian guppies (Poecilia reticulata) located in three drainages (northern coast, Caroni, and Oropouche) using seven microsatellite markers. They showed that all seven microsatellite loci are polymorphic and the observed number of alleles at a locus ranged from 5 to 44 , and heterozygosity ranged from 0.037 to 0.855 . Kucuk (2009) 
estimated genetic diversity among 64 guppies, Poecilia reticulata using nine RAPD markers. They showed that seven of nine RAPD markers are suitable for the investigation of diversity in the guppy. The genetic difference was low (ranged from 0.052 to 0.330). KuÈnstner et al. (2016) studied the genome of the Trinidadian guppy, Poecilia reticulata, and variation in the Guanapo population. They sequenced ten wild-caught male individuals and showed that the identified 5 million SNPs correspond to an average nucleotide diversity $(\pi)$ of 0.0025 . They concluded that the genome assembly and SNP map provide a rich resource for investigating adaptation to different predation regimes. The results of the study of guppy populations with different markers show that the diversity observed in the strains studied in our study with ISSR markers is higher than in other studies. It can be concluded that Iranian populations of guppies are less affected by selection pressure and are a good genetic resource for breeding programs.

The ISSR markers were used to study genetic diversity between three Paralichthys olivaceus populations by Liu et al. (2006), and it was shown that these markers are delicate and reproducible tools for population genetic analysis of fish. Moreover, Yun et al. (2006) demonstrated that determination of genetic diversity for domestic hatchery populations implicating the conservation of natural Paralichthys olivaceus resources. AMOVA analysis in this study showed that $54 \%$ genetic variance among populations is a high level of variance in twelve strains of aquarium guppy fish. Genetic diversity could be originated from various production systems and ecological conditions in which aquarium guppy fish in Iran have been historically preserved.

Since the adaptability of the aquarium guppy fish in Iran with their environments is the product of long-term selection pressures and cannot be attributed to recent times, admixed aquarium guppy fish should also be considered in the conservation strategies. An appropriate conservation strategy should maintain maximum genetic diversity in the global gene pool while maintaining breed diversity to reduce inbreeding and preserve genetically differentiated groups (Talle et al., 2005). In general, close genetic composition and similar environments indicate that similar and probably related conservation programs can be applied for these populations. However, control of crossbreeding, breeding centers development and improvement of recording systems conserve these populations under in situ conservation situations.

\section{Conclusion}

In recent years, with the wide application of DNA markers, the research of molecular markerassisted breeding has made great progress. The ISSR loci are highly polymorphic and could be used for genetic diversity studies. Further studies should be performed with more ISSRs to obtain higher accurate results. Genetic relationship among populations is a priority for managing genetic diversity. ISSR markers are efficient in discriminating each genotype at the molecular level. They can be used for genetic diversity analysis for aquarium guppy fish because a greater understanding of the species' potential is necessary for supporting long-term genetic improvement. Since ISSRs are simpler, faster, cheaper, and more effective than other markers, we suggest that this technique is an excellent alternative for low-cost genetic monitoring focused on improving control programs of species in regions with insufficient financial resources.

\section{Ethical Statement}

Not applicable.

\section{Funding Information}

This work was supported by Shahid Bahonar University of Kerman, the Vice Chancellor for Research and Technology (Grant number: G311/9620).

\section{Author Contribution}

Mohammadreza Mohammadabadi, Valentyna Oleshko and Alevtina Bazaeva conducted the experiments; Olexandr Oleshko and Leonid Heiko analyzed the data and wrote the manuscript; Iryna Starostenko, Zahra Roudbari and Jurii Kunovskii contributed to data analysis and revising the manuscript; Mohammadreza Mohammadabadi supervised the whole project.

\section{Conflict of Interest}

The authors declare that they have no known competing financial interests or personal 
relationships that could have appeared to influence the work reported in this paper.

\section{Acknowledgements}

We would like to thank the Vice Chancellor for Research and Technology of Shahid Bahonar University of Kerman for financial support to perform this research. We also appreciate the assistance of aquarium fish shops for their assistance throughout the experiment.

\section{References}

Ammiraju, J.S.S., Dholakia, B.B., Santra, D.K., Singh, H., Lagu, M.D., Tamhankar, S.A., Dhaliwal, H.S., Rao, V.S., Gupta, V.S. and Ranjekar, P.K. (2001). Identification of inter simple sequence repeat (ISSR) markers associated with seed size in wheat. Theoretical and Applied Genetics, 102, 726-732. https://link.springer.com/article/10.1007/s00122 0051703

Barazandeh, A., Moghbeli, S.M., Vatankhah, M. \& Mohammadabadi, M.R. (2012). Estimating nongenetic and genetic parameters of pre-weaning growth traits in Raini Cashmere goat. Tropical Animal Health and Production, 44, 811-817. https://doi.org/ 10.1007/s11250-011-9971-5

Becher, S.A., Russell, S.T. \& Magurran A.E. (2002). Isolation and characterization of polymorphic microsatellites in the Trinidadian guppy (Poecilia reticulata). Mol. Ecol. Note. 2, 456-458. https://doi.org/10.1046/j.14718286.2002.00276.x

Carvalho, G.R., Shaw, P.W., Magurran, A.E. \& Seghers, B.H. (1991). Marked genetic divergence revealed by allozymes among populations of the guppy Poecilia reticulata (Poeciliidae), in Trinidad. Biological Journal of the Linnean Society, 42, 389405.

https://doi.org/10.1111/j.1095-8312.1991.tb00571.x

Casu, M., Lai, T., Curini-Galletti, M., Ruiu, A. \& Pais, A. (2009). Identification of Mediterranean Diplodus spp. and Dentex dentex (Sparidae) by means of DNA Inter-Simple Sequence Repeat (ISSR) markers. Journal of Experimental Marine Biology and Ecology, 368, 147-152. https://doi.org/10.1016/j.jembe.2008.09.021

Earl, D.A. and vonHoldt, B.M. (2012). STRUCTURE HARVESTER: a website and program for visualizing STRUCTURE output and implementing the Evanno methd. Conservation Genetics Resources, 4, 359361. https://doi.org/10.1007/s12686-011-9548-7

Evanno, G., Regnaut, S. and Goudet, J. (2005). Detecting the number of clusters of individuals using the software STRUCTURE: a simulation study. Molecular Ecology, 14, 2611-2620. https://doi.org/10.1111/j.1365-

294X.2005.02553.x.

Excoffier, L., Smouse, P. \& Quattro, J. (1992). Analysis of molecular variance inferred from metric distances among DNA haplotypes: application to human mitochondrial DNA restriction sites. Genetics, 131, 479-491.

https://doi.org/10.1093/genetics/131.2.479

Fajen, A. \& Breden, F. (1992). Mitochondrial DNA sequence variation among natural populations of the Trinidad guppy, Poecilia reticulata. Evolution, 46, 1457-1465. https://doi.org/10.1111/j.15585646.1992.tb01136.x

Foo C.L., Dinesh, K.R., Lim, T.M., Chan, W.K. and Phang, V.P.E. (1995). Inheritance pf RAPD markers in the Guppy fish, Poecilia reticulate. Zoological Science, 12, 535-541. https://doi.org/10.2108/zsj.12.535.

Gholamhoseini, G.F., Mohammadabadi, M.R. \& Asadi Fozi, M. (2018). Polymorphism of the growth hormone gene and its effect on production and reproduction traits in goat. Iranian Journal of Applied Animal Sciences, 8, 653-659. http://ijas.iaurasht.ac.ir/article_544783.html

Han, Y. and Wang, H.Y. (2010). Genetic diversity and phylogenetic relationships of two closely related northeast China Vicia species revealed with RAPD and ISSR markers. Biochemistry Genetics, 48, 385401. https://doi.org/10.1007/s10528-009-9320-9.

Kharrati Koopaei, H., Mohammad Abadi, M.R., Ansari Mahyari, S., Tarang, A.R., Potki, P. \& Esmailizadeh, A.K. (2012). Effect of DGAT1 variants on milk composition traits in Iranian Holstein cattle population. Animal Science Papers and Reports, 30, 231-240. http://www.ighz.edu.pl/year-2012-vol30-no-3

Khoo, G., Lim, M.H., Gan, K.Y.D., Chen, F., Chan, W.K., Lim, T.M. \& Phang, V.P.E. (2002). Genetic diversity within and among feral populations and domesticated strains of the guppy (Poecilia reticulate) in Singapore. Marine Biotechnology, 4, 367-378. https://doi.org/10.1007/s10126-002-0007-z

Khoo, G., Lim, M.H., Suresh, H., Gan, D.K.Y., Lim, K.F., Chen, F., Chen W., Lim, T.M. \& Phang, V.P.E. (2003). Genetic linkage maps of guppy (Poecilia reticulate): assignment of RAPD markers to multipoint linkage groups. Marine Biotechnology, 5, 279-293. https://doi.org/10.1007/s10126-002-0072-3

Kucuk, S. (2009). Estimation of genetic differences among Guppies, Poesilia reticulate by RAPD markers. Adnan Menderes Üniversitesi Ziraat Fakültesi Dergisi, 7, 65-70.

https://dergipark.org.tr/en/pub/aduziraat/issue/2 $6428 / 278224$

KuÈnstner, A., Hoffmann, M., Fraser, B.A., Kottler, V.A., Sharma, E., Weigel, D. and Dreyeral, C. (2016). The Genome of the Trinidadian Guppy, Poecilia reticulata, and Variation in the Guanapo 
Population. PLOS ONE, 11, e0169087. https://doi.org/10.1371/journal.pone.0169087.

Labastida, E., Cobián, D., Hénaut, Y., García-Rivas, M.D.C., Chevalier, P.P. \& Rabet, S.M.M. (2015). The use of ISSR markers for species determination and a genetic study of the invasive lionfish in Guanahacabibes. Latin American Jjournal of Aquatic Research, 43, 1011-1018. http://dx.doi.org/10.3856/vol43-issue5-fulltext-21

Lata, H., Chandra, S., Techen, N., Khan, I. A. and ElSohly, M.A. (2010). Assessment of the genetic stability of micropropagated plants of Cannabis sativa by ISSR markers. Planta Medica, 76, 97-100. https://doi.org/10.1055/s-0029-1185945.

Leroy, X.J., Leon, K. and Branchard, M. (2000) Plant genomic instability detected by microsatelliteprimers. Electronic Journal of Biotechnology, 3, 510. https://www.scielo.cl/scielo.php?pid=S071734582000000200005\&script=sci_arttext

Lin, X.C., Lou, Y.F, Liu, J., Peng, J.S., Liao, G.L. and Fang, W. (2010). Crossbreeding of Phyllostachys species (Poaceae) and identification of their hybrids using ISSR markers. Genetics and Molecular Research, 9, 1398-1404. https://doi.org/10.4238/vol9-3gmr855.

Liu, G., Yu, Z., Bao, L., Bao B., Sun, X., Shi, Q. \& Liu, X. (2008). Population genetics studies of half-smooth tongue sole Cynoglossus semilaevis usin ISSR markers. Biochemical Systematic and Ecology, 36, 821-827.

https://doi.org/10.1016/j.bse.2008.09.003

Liu, Y.G., Chen, S.L., Li, J. \& Li, B.F. (2006). Genetic diversity in three Japanese flounder (Paralichthys olivaceus) populations revealed by ISSR markers. Aquaculture, 255, 565-572.

https://doi.org/10.1016/j.aquaculture.2005.11.032

Maltagliati, F., Lai, T., Casu, M., Valdesalici, S. \& Castelli, A. (2006). Identification of endangered Mediterranean cyprinodontiform fish by means of DNA inter-simple sequence repeats (ISSRs). Biochemical Systematic and Ecology, 34, 626-634. https://doi.org/10.1016/j.bse.2006.02.003

Marczewski, W., Hennig, J., and Gebhardt, C. (2002). The potato virus $\mathrm{S}$ resistance gene $\mathrm{Ns}$ maps to potato chromosome VIII. Theoretical and Applied Genetics, 105, 564-567.

https://link.springer.com/article/10.1007/s00122002-0976-3

Moghadaszadeh, M., Mohammadabadi, M.R. \& Esmailizadeh Koshkoieh, A. (2015). Association of Exon 2 of BMP15 Gene with the Litter Size in the Raini Cashmere Goat. Genetics in the 3rd Millennium, 13, 4062-4067.

https://www.cabdirect.org/cabdirect/abstract/20 163049310

Mohammadabadi, M.R. (2017). Inter-Simple Sequence Repeat loci Associations with Predicted Breeding Values of Body Weight in Kermani Sheep. Genetics in the 3rd Millennium, 14, 4383-4390. https://www.magiran.com/paper/1684636?lang= en

Mohammadabadi, M.R., Torabi, A., Tahmourespoor, M., Baghizadeh, A., Esmailizadeh Koshkoie, A. \& Mohammadi, A. (2010). Analysis of bovine growth hormone gene polymorphism of local and Holstein cattle breeds in Kerman province of Iran using polymerase chain reaction restriction fragment length polymorphism (PCR-RFLP). African Journal of Biotechnology, 9, 6848-6852.

https://doi.org/10.5897/AJB10.799

Mohammadi, A., Nassiry, M.R., Mosafer, J., Mohammadabadi, M.R. \& Sulimova, G.E. (2009). Distribution of BoLA-DRB3 allelic frequencies and identification of a new allele in the Iranian cattle breed Sistani (Bos indicus). Russian Journal of Genetics, 45, 198-202. https://doi.org/10.1100/2012/863024

Nagaraju, J., Kathirvel, M., Kumar, R.R., Siddiq, E.A. and Hasnain, S.E. (2002). Genetic analysis of traditional and evolved Basmati and non-Basmati rice varieties by using fluorescence-based ISSR-PCR and SSR markers. Proceedings of the National Academy of Sciences of the United States of America, 99, 5836-5841.

https://doi.org/10.1073/pnas.042099099.

Nassiry, M.R., Shahroodi, F.E., Mosafer, J., Mohammadi, A., Manshad, E., Ghazanfari, S., Mohammad Abadi, M.R. \& Sulimova, G.E. (2005). Analysis and frequency of bovine lymphocyte antigen (BoLADRB3) alleles in Iranian Holstein cattle. Russian Journal of Genetics, 41, 664-668. https://doi.org/10.1007/s11177-005-0142-5

Paris, H.S., Yonash, N., Portnoy, V., Mozes-Daube, N., Tzuri, G. and Katzir, N. (2003). Assessment of genetic relationships in Cucurbita pepo (cucurbitaceae) using DNA markers. Theoretical and Applied Genetics, 106, 971-978.

https://link.springer.com/article/10.1007/s00122002-1157-0

Pasandideh, M., Mohammadabadi, M.R., Esmailizadeh, A.K. \& Tarang, A. (2015). Association of bovine PPARGC1A and OPN genes with milk production and composition in Holstein cattle. Czech Journal of Animal Science, 60, 97-104.

https://doi.org/10.17221/8074-CJAS

Paterson, I.G., Crispo, E., Kinnison, M.T., Hendry, A.P. \& Bentzen, P. (2005). Characterization of tetranucleotide microsatellite markers in guppy (Poecilia reticulata). Molecular Ecology, Notes 5, 269-271. https://doi.org/10.1111/j.1471-8286.2005.00895.x

Peakall, R. \& Smouse, P.E. (2012). GenAlEx 6.5: genetic analysis in Excel. Population genetic software for teaching and research-an update. Bioinformatics, 28, 2537-2539.

https://doi.org/10.1093/bioinformatics/bts460

Rajwade, A.V., Arora, R.S., Kadoo, N.Y., Harsulkar, A.M., Ghorpade, P.B. and Gupta, V.S. (2010). Relatedness 
of Indian flax genotypes (Linum usitatissimum L.): an inter-simple sequence repeat (ISSR) primer assay. Molecular Biotechnology, 45, 161-170. https://doi.org/10.1007/s12033-010-9256-7.

Saad, Y.M., Rashed, M.A., Atta, A.H. \& Ahmed, N.E. (2012). Genetic Diversity among Some Tilapia species Based on ISSR Markers. Life Science Journal 9, 4841-4846.

http://www.lifesciencesite.com/lsj/life0904/

Sambrook, J. \& Russell, D.W. (2001). Molecular cloning: a laboratory manual. Cold Spring Harbor, New York: Cold Spring Harbor Laboratory Press. https://www.cshlpress.com/pdf/sample/2013/MC 4/MC4FM.pdf

Sarwat, M. (2012). ISSR: A Reliable and Cost-Effective Technique for Detection of DNA Polymorphism. Chapter (9) in book: Nikolaus J. Sucher et al. (eds.), Plant DNA Fingerprinting and Barcoding: Methods and Protocols, Methods in Molecular Biology, vol. 862, (C) Springer Science+Business Media, LLC 2012. DOI 10.1007/978-1-61779-609-8_9.

Shamsalddini, S., Mohammadabadi, M.R. \& Esmailizadeh, A.K. (2016). Polymorphism of the prolactin gene and its effect on fiber traits in goat. Russian Journal of Genetics, 52, 461-465. https://doi.org/10.7868/s0016675816040093

Shen, X., Yang, G. \& Liao, M. (2007). Development of 51 genomic microsatellite DNA markers of guppy (Poecilia reticulata) and their application in closely related species. Molecular Ecology Notes, 7, 302306. https://doi.org/10.1111/j.1471-8286.2006.01589.x

Suk, H.Y. \& Neff, B.D. (2009). Microsatellite genetic differentiation among populations of the Trinidadian guppy. Heredity, 102, 425-434. https://doi.org/10.1038/hdy.2009.7

Talle, S.B., Chenyabuga, W.S., Fimland, E., Syrstad, O., Meuwissen, T. \& Klungland, H. (2005). Use of DNA technologies for the conservation of animal genetic resources: A review. Acta Agriculturae Scandinavica, Section A - Animal Science, 55, 1-8. https://doi.org/10.1080/09064700510009315

Tamhankar, S., Ghate, V., Raut, A. and Rajput, B. (2009). Molecular profiling of "Chirayat" complex using Inter Simple Sequence Repeat (ISSR) markers. Planta Medica, 75, 1266-1270. https://doi.org/10.1055/s-0029-1185543.

Tong, J., Yu, X. \& Liao, X. (2005). Characterization of a highly conserved microsatellite marker with utility potentials in cyprinid fishes. Journal of Applied Ichthyology, 21, 232-235.

https://doi.org/10.1111/j.1439-0426.2005.00625.x

Vajed Ebrahimi, M.T., Mohammad Abadi, M.R. \& Esmailizadeh, A.K. (2017). Using microsatellite markers to analyze genetic diversity in 14 sheep types in Iran. Archives Animal Breeding, 60, 183189.

https://doi.org/10.5194/aab-60-183-2017

Watanabe, T., Yoshida, M., Nakajima, M. \& Taniguchi, N. (2003). Isolation and characterization of 43 microsatellite DNA markers for guppy (Poecilia reticulata). Molecular Ecology Notes, 3, 487-490. https://doi.org/10.1046/j.14718286.2003.00490.x

Wu, Y., Shi, H.M., Bao, Z., Wang, M.Y., Tu, P.F. and Li, X.B. (2010). Application of molecular markers in predicting production quality of cultivated Cistanche deserticola. Biological and Pharmaceutical Bulletin, 33, 334-339. https://doi.org/10.1248/bpb.33.334.

XLSTAT. (2017). Data analysis and statistical solution for Microsoft excel. Addinosoft, Paris, France. https://www.xlstat.com/en/company/about-us

Yuan, X.F., Dai, Z. H., Wang, X.D. and Zhao, B. (2009). Assessment of genetic stability stability in tissuecultured products and seedlings of Saussurea involucrata by RAPD and ISSR markers. Biotechnology Letters, 31, 1279-1287. https://doi.org/10.1007/s10529-009-9984-6.

Yun, G., Song, L.Ch., Li, J. \& Li, B.F. (2006). Genetic diversity in three Japanese flounder (Paralichthys olivaceus) populations revealed by ISSR markers. Aquaculture, 255, 565-572. https://doi.org/10.1016/j.aquaculture.2005.11.032

Zamani, P., Akhondi, M., Mohammadabadi, M.R., Saki, A.A., Ershadi, A., Banabazi, M.H. \& Abdolmohammadi, A.R. (2011). Genetic variation of Mehraban sheep using two inter simple sequence repeat (ISSR) markers. African Journal of Biotechnology, 10, 1812-17. https://doi.org/10.5897/AJB10.1986

Zhang, F., Lv, Y., Dong, H. and Guo, S. (2010). Analysis of genetic stability through intersimple sequence repeats molecular markers in micropropagated plantlets of Anoectochilus formosanus Hayata, a medicinal plant. Biological and Pharmaceutical Bulletin, 33, 384-388. https://doi.org/10.1248/bpb.33.384. 